\title{
HENOCH-SCHÖNLEIN PURPURA NEPHRITIS IN CHILDREN: PROGNOSIS AND TREATMENT EXPERIENCES
}

\author{
Ana Vujic ${ }^{1,2}$, Jasmina Knezevic ${ }^{1,2}$, Zoran Igrutinovic ${ }^{1,2}$, Sveta Jankovic ${ }^{2}$
${ }^{1}$ Paediatrics department, Faculty of medical sciences, University of Kragujevac, Serbia \\ ${ }_{2}^{2}$ Paediatrics clinic, Clinical center Kragujevac, Serbia
}

\author{
NEFRITIS U HENOH-ŠENLAJNOVOJ PURPURI KOD DECE: \\ ISKUST VA U PROGNOZI I TERAPIJI \\ Ana Vujić ${ }^{1,2}$, Jasmina Knežević ${ }^{1,2}$, Zoran Igrutinović ${ }^{1,2}$, Sveta Janković ${ }^{2}$ \\ ${ }^{1}$ Katedra za pedijatriju, Fakultet medicinskih nauka, Univerzitet u Kragujevcu, Srbija \\ ${ }^{2}$ Klinika za pedijatriju, Klinički centar Kragujevac, Srbija
}

Received / Primljen: 17.03.2016.

Accepted / Prihvaćen: 11.05.2016.

\begin{abstract}
Henoch-Schönlein purpura is a type of systemic small vessel vasculitis. The dominant manifestation is the cutaneous component, the illness is self-limiting in nature, and the prognosis and outcome depend mostly on renal manifestations. We analysed the associations among clinical and laboratory parameters with the prognosis and outcome of HSP in children hospitalised at the Paediatrics clinic, Clinical Centre, Kragujevac between January 2011 and January 2012. Children who developed nephritis were older on average and all manifested with arthritis, abdominal complaints, microhaematuria, elevated D-dimer levels in the serum, and significant proteinuria and microalbuminuria ( $\geq 300 \mathrm{mg} / \mathrm{L}$ ), and two children had pre-existing allergic conditions. All three children with repeatedly positive proteins in the morning sample urine test had significant proteinuria ( $\geq 0,5 \mathrm{~g} / 24 \mathrm{~h})$ and microalbuminuria ( $\geq$ $300 \mathrm{mg} / \mathrm{L}$ ). These children had more bursts of rash and more severe and lasting abdominal pain and arthritis compared to children with normal urine tests. They were therefore treated with glucocorticoids and an angiotensin-converting enzyme inhibitor. The glomerular filtration rate measured by determining creatinine clearance was normal in all patients. These patients were diagnosed with Henoch-Schönlein purpura nephritis, and their condition was regularly monitored. Analysis of this group of patients demonstrated that the average age of 8 years and abdominal complaints were indicative of nephritis development.. Because both of these parameters are easily noted at disease onset, we suggest careful monitoring of disease course in these children.
\end{abstract}

Keywords: nephritis, Henoch-Schönlein purpura, children

\section{SAŽETAK}

Henoh-Šenlajnova purpura je sistemski vaskultis malih krvnih sudova. Dominantna manifestacija je kutana komponenta, bolest je najčeće samoograničavajuća, a ishod $i$ prognoza najviše zavise od renalnih manifestacija. Bavili smo se povezanošću kliničkih i laboratorijskih pokazatelja u prognozi $i$ ishodu Henoh-Šenlajnova purpure kod dece hospitalizovane na Klinici za pedijatriju Kliničkog centra Kragujevac, u periodu od januara 2011. do januara 2012. godine. Deca u grupi sa nefritisom su bila starije srednje životne dobi, sva su ispoljila artritis, abdominalne tegobe, mikrohematuriju, povišene vrednosti D-dimera u serumu, značajnu proteinuriju i mikroalbuminuriju ( $\geq 300 \mathrm{mg} / \mathrm{L}$ ), a kod dvoje je utvrdeno ranije postojanje alergijskih stanja. Kod svo troje dece sa ponovljenim pozitivnim nalazom proteina u urinu nadena je značajna proteinurija ( $\geq 0,5 \mathrm{~g} / 24 \mathrm{~h})$ i mikroalbuminurija ( $\geq 300 \mathrm{mg} / \mathrm{L})$. Ova deca su imala $i$ više naleta ospe, izraženije $i$ dugotrajnije abdominalne tegobe $i$ artritis od dece sa urednim nalazom u urinu. Njima je ordinirana kortikosteroidna terapija uz inhibitor angiotenzin-konvertujućeg enzima. Jačina glomerularne filtracije merena klirensom kreatinina bila je uredna kod svih pacijenata. Kod svih je postavljena dijagnoza Henoh-Šenlajn purpura nefritis $i$ njihovo stanje se redovno prati. U našoj grupi ispitanika se ispostavilo da je prosečna starost dece od 8 godina $i$ postojanje abdominalnih tegoba, predznak nastanka nefritisa. Budući da su oba parametra lako uočljiva na samom početku bolesti, smatramo da je potrebno brižljivo praćenje toka bolesti kod ove dece.

Ključne reči: nefritis, Henoh-Šenlajn purpura, deca

\section{ABBREVIATIONS}

ACE-I - angiotensin converting enzyme inhibitor; C3 - complement component 3;

EULAR - European league against rheumatism; Gd-IgA1 - Galactose deficient IgA1 antibodies; HSP - Henoch-Schönlein purpura; HSPN - Henoch-Schönlein purpura nephritis;

IgA - immunoglobulin A;

ISKDC - International Study of Kidney Disease in Children; KDIGO - Kidney Disease Improving Global Outcome; PRES - paediatric rheumatology european society; PRINTO - The paediatric rheumatology international trials organisation 


\section{INTRODUCTION}

Henoch-Schönlein purpura (HSP) is a systemic small vessel vasculitis. It occurs in some people as a consequence of the immune response to exogenous and endogenous antigens, during which aberrant IgA1 antibodies are produced. Because of this response, HSP is also called IgA vasculitis even though aberrant IgA antibodies cannot be confirmed in all patients. The dominant clinical manifestation is the cutaneous eruption, a purpuric rash that usually develops in several bursts. Skin changes begin to pale after a couple of days, changing their colour from dark red to reddish-yellow, and finally fading away after a few days without leaving a scar. The diagnosis is usually based on this clinical finding. The commonly used 2010 EULAR/PRINTO/PRES criteria (1) include palpable purpura and one of the following: abdominal pain, IgA deposits in biopsy findings, arthritis/arthralgia, or nephropathy. The disease is most often self-limiting, and the outcome and prognosis depend mostly on renal manifestations.

Nephropathy occurs in about a third of patients with HSP, of which $30-50 \%$ develop haematuria and/or proteinuria, 7\% develop nephritic or nephrotic syndrome, and 1-2\% develop chronic kidney disease. Nephropathy clinically manifests within the first 4 weeks in $75 \%$ of patients, rarely 9 months after HSP onset, and is an extremely rare first sign of HSP. Galactose deficient IgA1 antibodies (Gd-IgA1) are probably most important for the pathogenesis of HSP nephritis (HSPN). The presence of these antibodies in HSP patients' serum predisposes them to nephritis $(2,3)$. The immune system recognizes aberrantly glycosylated IgA antibodies, making anti-glycan antibodies, which together form immune complexes. These immune complexes bind to mesangium and initiate the process of renal damage by activating the complement cascade that eventually leads to leukocytoclastic vasculitis. This pathologic process matches that in IgA nephropathy (4). The relationship between the two diseases is demonstrated by the case of a girl that developed symptoms characteristic of HSPN 5 years after the initial onset of IgA nephropathy (5). A retrospective study conducted in Turkey involving 430 patients showed that girls, children with atypical presentations, and early introduction of glucocorticoids have an increased risk of producing renal damage, and that relapses are more frequent in children treated with glucocorticoids (6).

The variety of clinical presentations, possible complications, and treatment approaches for HSP led us to retrospectively explore the relationships of clinical and laboratory parameters with the prognosis and outcomes of HSP and especially with the treatment and outcomes of HSP nephritis in children hospitalised at the Paediatrics Clinic, Clinical Centre, Kragujevac in the period between January 2011 and January 2012.

\section{PATIENTS AND METHODS}

The data on the patients treated at the Paediatrics Clinic, Clinical Centre, Kragujevac from January 2011 to January 2012 were collected retrospectively. Each patients' data were obtained from written and electronic medical files, and demographic, clinical, and laboratory information were extracted.

The patients were diagnosed with HSP if they manifested the characteristic rash, abdominal symptoms, arthritis, or other symptoms, according to the 2010 EULAR/PRINTO/PRES criteria (1). Microhaematuria was defined as the presence of 5 or more erythrocytes per field at $500 \mathrm{x}$ amplification; macrohaematuria was defined as visible red urine with correlating microscopic findings of erythrocytes in the urine sample test; significant proteinuria was defined as urine protein concentration above $0,5 \mathrm{~g}$ in the 24 -hour urine collection test; hypertension was defined as multiple measurements of blood pressure above the 95th percentile for age, height and gender. The creatinine clearance reference range from 1,47 to $2,28 \mathrm{~mL} / \mathrm{sec} / 1.73 \mathrm{~m}^{2}$ was used. Because there was a small number of patients included in the study, only descriptive statistical methods were used.

\section{RESULTS}

Patient clinical and laboratory data are shown in table 1. We included a total of six patients, 3 boys and 3 girls, aged 3 to 14 years. All children were diagnosed with HSP based on clinical presentation of purpuric, non-thrombocytopenic rash and other non-cutaneous manifestations. Five children presented with arthritis, and abdominal discomfort without gastrointestinal bleeding was noted in three. None of the included children manifested with macrohematuria, hypertension or elevated IgA serum level. We identified some sig-

Table 1. Patient clinical and laboratory data.

\begin{tabular}{|l|l|l|}
\hline Patients $^{1}$ & No nephritis (3) & Nephritis (3) \\
\hline Gender & $1: 2(\mathrm{~m}: \mathrm{f})$ & $2: 1(\mathrm{~m}: \mathrm{f})$ \\
\hline Age (mean) & 5,33 & 8,00 \\
\hline Purpura & $3(100 \%)$ & $3(100 \%)$ \\
\hline Arthritis & $2(66,7 \%)$ & $3(100 \%)$ \\
\hline Abdominal discomfort & 0 & $3(100 \%)$ \\
\hline Microhaematuria & $2(66,7 \%)$ & $3(100 \%)$ \\
\hline Macrohaematuria & 0 & 0 \\
\hline D-Dimer $(>230 \mathrm{ng} / \mathrm{mL})$ & $2(66,7 \%)$ & $3(100 \%)$ \\
\hline Proteinuria $\left(>0.5 \mathrm{~g} / 24^{\mathrm{h}}\right)$ & $1(33,3 \%)$ & $3(100 \%)$ \\
\hline Creatinine clearance & 0 & $2(66,7 \%)$ \\
\hline Microalbumin $(>300 \mathrm{mg} / \mathrm{L})$ & 0 & $3(100)$ \\
\hline Cholesterol & 0 & $2(66,7 \%)$ \\
\hline Infectious agent confirmed & $1(33,3 \%)$ & $1(33,3 \%)$ \\
\hline Total serum IgA $(>4 \mathrm{~g} / \mathrm{L})$ & 0 & 0 \\
\hline Coplement level & 0 & $1(33,3 \%)$ \\
\hline Allergies & 0 & $2(66,7 \%)$ \\
\hline
\end{tabular}

${ }^{1}$ The total number and the percentage of patients are shown for each group. ${ }^{2}$ The number of cases with values below reference is shown. Reference values are 1.47 to $2.28 \mathrm{~mL} / \mathrm{sec} / 1.73 \mathrm{~m} 2$.

${ }^{3}$ The number of cases with values below reference is shown. Reference values are C3 0,9 to $1,8 \mathrm{~g} / \mathrm{L}$ and C4 0,1 to $0,4 \mathrm{~g} / \mathrm{L}$. 
nificant differences among children who developed nephritis and those who did not. As presented in table 1, children in the nephritis group were older on average (8,00 years old), and all manifested with arthritis, abdominal discomfort, microhematuria, elevated D-dimer levels, significant proteinuria $(>0,5 \mathrm{~g} / 24 \mathrm{~h})$ and microalbuminuria $(>300 \mathrm{mg} / \mathrm{L})$. Two of three children in the nephritis group had prior confirmation of multiple allergies, whereas the children in the group without nephritis had no allergic conditions.

All patients were initially put on a hypoallergenic diet and an antihistamine. Antimicrobials were introduced in those patients with signs of infection. The general condition of the patients as well as clinical and laboratory parameters were monitored regularly.

Patients in both groups had repeated bursts of the typical rash. Finding proteins in the morning urine sample tests was particularly important because it signified the development of renal damage and the occurrence of nephritis. In three children with repeated positive proteins in the morning urine sample test, a 24-hour urine collection test was performed. Significant proteinuria $(>0.5 \mathrm{~g} / 24 \mathrm{~h})$ and microalbuminuria ( $>300 \mathrm{mg} / \mathrm{L}$ ) were found in all three. These children had more bursts of rash and more pronounced and lasting abdominal pain and arthritis than children with normal urine findings. Two out of the three children who developed signs of renal damage were known to have allergies to nutritive allergens and medications. Two of these three children had an increased cholesterol level during the course of illness. These test results were understood as signs of disease progression towards renal involvement and the development of HSP nephritis, so treatment with prednisone and angiotensin converting enzyme inhibitor (ACE-I) was initiated. Prednisone treatment succeeded in stopping further bursts of rash in two patients, whereas in the third patient, the rash persisted until an infectious agent was isolated from the stool sample and treated adequately. Positive proteins in the morning urine sample test with significant proteinuria and hypercholesterolemia continued under prednisone treatment for several weeks while the glomerular filtration rate remained normal in all three children. Renal biopsy was performed in one of the patients because of the nephrotic range proteinuria, and the histology results indicated a mesangioproliferative glomerulonephritis with crescents and positive staining for IgA and C3 in the mesangium. Treatment of this patient was then continued with azathioprine and an ACE-I. Urinary remission was achieved in all patients within 5 weeks of initiating nephritis treatment. There were no relapses of purpura or nephritis. All patients are presently without any specific therapy and maintaining normal renal function; their condition is monitored through regular follow-up.

\section{DISCUSSION}

We looked into the relationships among clinical and laboratory parameters and the prognosis and outcome of
HSP, and the results indicate the significance of nephritis in HSP morbidity. Older age, abdominal complaints, previous allergic conditions, and duration and intensity of symptoms indicate that the development of nephritis is more likely in patients with such a presentation. Although our study involved a small number of patients, the results are in line with the results of most other studies that have been performed on a much larger case series. Older age, abdominal complaints and persistence of rash have been confirmed as risk factors for developing nephropathy $(7,8)$. Positive signs of type I hypersensitivity reactions are common in HSP patients, and earlier studies have shown that they are predictors of nephropathy $(9,10)$. Identification of new and careful monitoring of known patients with type I hypersensitivity reactions would have been easy and useful, but no such recommendations exist because the new results dispute the rationale for such actions (11). Female gender has been shown to predict a poorer long-term outcome (12), but we could not confirm this in our group.

Because HSP is the most common vasculitis in children, HSPN is a respectively common form of glomerulonephritis, which was illustrated by the results of the study conducted in Dalmatia, where during a 10-year period, of all the renal biopsies performed, $10,8 \%$ of glomerulonephritis cases were due to the renal involvement of HSP (13). HSPN is usually manifested by acute phases of glomerular inflammation, during which histology examination can reveal endocapillary and mesangial proliferation. Older lesions contain fibrin deposits and epithelial crescents that could resolve completely or evolve to chronic lesions. The histology results of a mesangioproliferative glomerulonephritis with crescents and positive IgA and C3 staining in one of the patients matches the findings observed in HSPN patients (14). Complete and lasting urinary remission in this patient was achieved only after introducing azathioprine. Patients in the nephritis group had persistent rash and pronounced abdominal complaints for which they were treated with glucocorticoids early in the course of illness before signs of renal damage were evident. However, that treatment did not prevent the development of nephritis. To date, there have not been any treatment methods that significantly shortened the duration of HSP, and there is conflicting evidence in the literature that, on the one hand, suggest that early glucocorticoid treatment reduces the chance of persistent renal disease, relapses and the need for surgical interventions (15), and on the other, that a short course of glucocorticoids is not justified in preventing persistent renal disease (7). There are only a few quality clinical trials on treatment options, especially on treating nephropathy with immunosuppressants (16).

Many investigators aimed their research at determining risk factors for poor outcomes and finding adequate therapies. The blood pressure level at the disease onset is not a good indicator of the outcome (17). Isolated haematuria and/or mild proteinuria early in the course of illness usually has a good prognosis, but $18 \%$ of patients with mild proteinuria have poor outcomes (12). Clinical 
and biochemical prognostic parameters that could point to the occurrence of severe nephropathy or end-stage renal disease are haematohesia, persistence of rash, signs of nephritic or nephrotic syndrome and finding numerous glomerular crescents (18). Other researchers have published the results of multivariate risk factor analysis that show a glomerular filtration rate below $70 \mathrm{~mL} / \mathrm{min} / 1,73$ $\mathrm{m}^{2}$ and growing proteinuria after 3 years of follow-up to better correlate with progression to chronic renal disease than reduced renal function, severe proteinuria, hypertension or presence of crescents at disease onset (17). The prognostic value of histology change grades according to the International Study of Kidney Disease in Children (ISKDC) classification has been investigated several times, and it appears to be significant, especially for short-term outcomes (12). There are results that show the possibility of using only the presence of crescents for predicting outcomes in a way that if over 50\% of glomeruli contain crescents or demonstrate signs of sclerosis, there is a greater likelihood for the occurrence of progressive renal disease, renal insufficiency or end stage renal disease (7).

Our patients who developed nephritis had all been treated with ACE-Is and glucocorticoids. Our patients who developed nephritis had all been treated with ACEIs and glucocorticoids. The glucocorticoid doses did not exceed $2 \mathrm{mg} / \mathrm{kg}$, nor did we use pulse therapy in any of the cases. The nephritis, however, was not controlled efficiently in the one patient whose proteinuria reached the nephrotic range, where treatment was continued successfully with azathioprine after the biopsy results were reviewed. KDIGO guidelines for HSPN based the choice of treatment on the degree of proteinuria, and because there was no high quality evidence for the use of angiotensin-converting enzyme inhibitors or angiotensin receptor blockers or immunosuppressants in HSPN treatment, the recommendations are founded on the research of IgA nephropathy treatment (19). This guideline does not consider the histology findings to be significant due to the results that were published by Ronkainen and colleagues stating that the first kidney biopsy findings for each patient do not typically correlate with the long-term outcome (20). Additionally, many papers have been published on using various immunosuppressants and other therapies with good outcomes in case series or isolated cases of patients with high grade proteinuria or histology changes. Use of glucocorticoids, ACE inhibitors and azathioprine in our group had good long-term effects in all patients with nephritis. The decisions on which type of treatment to use were made were based on experience or on the results of the case series, which showed that intensifying treatment reduces the chance for developing chronic renal disease and that delaying treatment can produce an unfavourable outcome. Previous statements related mainly to the treatment of patients with severe renal disorders at disease onset, which can manifest itself as renal failure, nephrotic, nephritic or nephritic-nephrotic syndrome and numerous glomerular crescents. These presentations are shown to be predictors of a poor outcome (21). Similar biopsy results at the onset of HSPN have a variable evolution (22), but the significance of the degree of proteinuria for nephritis outcomes has been validated several times $(12,17)$. Still, the unknowns about HSPN pathophysiology make it difficult to find clues from basic research as to which type of treatment is best. New research should indicate the best choice and the role of immunosuppressants as well as other therapies in HSPN.

\section{CONCLUSION}

HSPN is a rare disease with the potential for development of long-term renal damage. The occurrence of nephritis merits long-term follow-up of these patients for possible end-stage renal disease. Renal damage in HSP has a good overall prognosis in childhood, but in some cases, nephritis progresses to renal failure. Even low grade histology changes carry a risk for chronic renal disease. On the other hand, high grade lesions can resolve completely. The treatment of HSPN relies on many immunosuppressants with confirmed efficacy in case series. However, the evidence from well-designed, randomised controlled trials are needed, especially for the treatment of severe cases of HSPN. The choice of therapy should be based on clinical and laboratory parameters of HSPN severity. The patient age and abdominal complaints were indicators of nephritis in our group. Because both of these parameters are easy to monitor at any time during the disease course, we suggest careful follow-up of these HSP patients for early and adequate detection of nephritis.

\section{REFERENCES}

1. EULAR/PRINTO/PRES criteria for Henoch-Schönlein purpura, childhood polyarteritis nodosa, childhood Wegener granulomatosis and childhood Takayasu arteritis: Ankara 2008. Part I: Overall methodology and clinical characterisation. Ann Rheum Dis 2010; 69(5): 790-7. doi:10.1136/ard.2009.116657

2. Allen AC, Willis FR, Beattie TJ, Feehally J. Abnormal IgA glycosylation in Henoch-Schönlein purpura restricted to patients with clinical nephritis. Nephrol Dial Transplant 1998; 13: 930-4. PMID: 9568852

3. Lau KK, Wyatt RJ, Moldoveanu Z, Tomana M, Julian BA, Hogg RJ, et al. Serum levels of galactose-deficient IgA in children with IgA nephropathy and HenochSchönlein purpura. Pediatr Nephrol 2007; 22: 2067-72. PMID: 17943324

4. Suzuki H, Fan R, Zhang Z, Brown R, Hall S, Julian BA, et al. Aberrantly glycosylated IgA1 in IgA nephropathy patients is recognized by IgG antibodies with restricted heterogeneity. J Clin Invest 2009; 119(6): 1668-77. doi: 10.1172/JCI38468. 
5. Chishiki M, Kawasaki Y, Kaneko M, Ushijima Y, Ohara $\mathrm{S}$, Abe $\mathrm{Y}$, et al. A 10-year-old girl with IgA nephropathy who 5 years later developed charactheristic features of Henoch-Schönlein purpura nephritis. Fukushima J Med Sci 2010; 56(2):157-61. PMID: 21502718

6. Anil M, Aksu N, Kara OD, Bal A, Anil AB, Yavaşcan $\mathrm{O}$, et al. Henoch-Schonlein purpura in children from western Turkey: a retrospective analysis of 430 cases. Turk J Pediat. 2009; 51: 429-36. PMID: 20112597

7. Bogdanović R. Henoch-Schönlein purpura nephritis in children: risk factors, prevention and treatment. Acta Paediatr. 2009; 98(12):1882-9. doi:10.1111/j.16512227.2009.01445.x

8. Jauhola O, Ronkainen J, Koskimies O, Ala-Houhala M, Arikoski P, Hölttä T, et al. Renal manifestations of Henoch-Schönlein purpura in a 6-month prospective study of 223 children. Arch Dis Child 2010; 95: 877-82. doi:10.1136/adc.2009.182394

9. Namgoong MK, Lim BK, Kim JS. Eosinophil cationic protein in Henoch-Schönlein purpura and in IgA nephropathy. Pediatr Nephrol 1997; 11:703-706. PMID: 9438647

10. Shu KH, Lu YS, Chen CH, Sheu SS, Chan LP, Lian JD. Serum immunoglobulin E in IgA nephropathy. Clin Nephrol 1995; 44: 86-90. PMID: 8529314

11. Chen AC, Lin CL, Shen TC, Li TC, Sung FC, Wei CC. Association between allergic diseases and risks of HSP and HSP nephritis: a population-based study. Pediatr Res. 2015 Dec 21. doi: 10.1038/pr.2015.271 [Epub ahead of print]

12. Edström Halling S, Söderberg MP, Berg UB. Predictors of outcome in Henoch-Schönlein nephritis. Pediatr Nephrol 2010; 25: 1101-8. doi: 10.1007/s00467010-1444-y.

13. Bazina M, Glavina-Durdov M, Scukanec-Spoljar M, et al. Epidemiology of renal disease in children in the region of Southern Croatia: A 10-year review of regional renal biopsy databases. Med Sci Monit 2007; 13(4): CR172-176. PMID: 17392646

14. Haas M. IgA nephropathy and Henoch-Schönlein purpura. In: Jennette JC, Olson JL, Schwartz MM, Silva FG, eds. 6th ed. Philadelphia, Lippincott Williams \& Wilkins, 2007: 423-86.

15. Weiss PF, Feinstein JA, Xianqun L, Burnham JM, Feudtner C. Effects of Corticosteroid on Henoch-Schönlein Purpura: A Systematic Review. Pediatrics 2007; 120(5): 1079-87. doi: 10.1542/peds.2007-0667

16. Boyd JK, Cheung CK, Molyneux K, Feehally J, Barratt J. An update on the pathogenesis and treatment of IgA nephropathy. Kidney International 2012; 81, 833-43. doi:10.1038/ki.2011.501.

17. Coppo R, Andrulli S, Amore A, Gianoglio B, Conti G, Peruzzi L, et al. Predictors of Outcome in Henoch-Schönlein Nephritis in Children and Adults. Am J Kidney Dis 2006; 47(6): 993-1003. doi:10.1053/j.ajkd.2006.02.178

18. Scheinfeld NS. Pediatric Henoch-Schonlein Purpura. In: Langman CB, chief editor. [Cited Feb 10 2016] Available at http://emedicine.medscape.com/ article/984105-overview

19. Chapter 11: Henoch-Schönlein purpura nephritis. In: KDIGO Clinical Practice Guideline for Glomerulonephritis. Kidney International Supplements (2012) 2, 139; doi:10.1038/kisup.2012.9

20. Ronkainen J, Nuutinen M, Koskimies O. The adult kidney 24 years after childhood Henoch-Schonlein purpura: a retrospective cohort study. Lancet 2002; 360: 666-70. PMID: 12241872

21. Mir S, Yavascan O, Mutlubas F, Yeniay B, Sonmez F. Clinical outcome in children with Henoch-Schönlein nephritis. Pediatr Nephrol 2007; 22: 64-70. doi 10.1007/ s00467-006-0278-0

22. Davin JC, Coppo R. Henoch-Schönlein purpura nephritis in children. Nat Rev Nephrol 2014; 10: 563-73. doi:10.1038/nrneph.2014.126 